\title{
Kesalahan Penggunaan Jouken Hyougen pada Pembelajar Bahasa Jepang Level Menengah Atas
}

\author{
Gilang Auliya Prasetyo Widodo*, Dedi Sutedi \\ Program Studi Pendidikan Bahasa Jepang, Universitas Pendidikan Indonesia, Bandung, Indonesia
}

email: gilang_apw@yahoo.co.jp*

DOI: $10.20884 / 1 . j l i t e r a .2020 .2 .1 .2593$

\begin{abstract}
This study discusses the mistake of the jouken hyougen in advanced-level Japanese language learners. Therefore the research aims to find out what mistakes are often experienced by upper-middle Japanese language learners in understanding the use of jouken hyougen to,tara, nara, dan ba. Then this study aims to provide advice or efforts to minimize mistakes using jouken hyougen. The method used in this research is descriptive qualitative. Data collection was carried out using test and interview instruments. The form of test questions is a test to translate as many as 5 questions and a test of true or false as many as 5 questions which include jouken hyougen of to, tara, nara, and ba. Then after the test ends, interview the respondent to find out why the respondent is wrong in answering the questions given. The subjects of this study were Japanese middle-level Japanese language learners. They are advanced learners with level 3 to level 1 Japanese language skills (JLPT). Based on the data that has been obtained, it is known that middle-

Keywords:

Analisis kesalahan; jouken hyougen; pengandaian; bahasa Jepang

Article Info:

First received:

14 April 2020

Available online:

30 November 2020 level learners still often experience errors. As in the use of tara to show presuppositions related to time and this condition of presupposition related to time are wrong if used word moshi. The error has a percentage of errors of $86.4 \%$ or 32 people from a total of 37 respondents answered incorrectly. In the use of the form ba and to which shows something that is natural, the respondent is considered quite good in understanding the use of the supposition ba and to. From the test data that has been tested only $16.2 \%$ or 6 people out of a total of 37 respondents answered incorrectly. Based on the results of interviews with respondents, admitted that they did not know the rules that apply to every form of presupposition of to, tara, nara, and ba. Efforts that can be made to minimize mistakes are as instructors to optimize understanding of spending on the material jouken hyougen, motivates learners to find out for themselves from various sources outside the book obtained during learning, then ask the native speaker if you want to know when the context of jouken hyougen to, tara, nara, and ba is used.
\end{abstract}

\section{PENDAHULUAN}

Minat dan antusias pembelajar bahasa Jepang di Indonesia semakin meningkat. Menurut survei yang dilakukan oleh Japan Foundation, Indonesia menempati peringkat lima dengan pembelajar bahasa Jepang terbanyak di dunia. Namun dalam mempelajari bahasa asing atau bahasa yang tidak identik dengan bahasa ibu tentunya membuat pembelajar menemukan kendala dan kesulitan dalam mempelajarinya. Sehingga pembelajar seringkali melakukan kesalahan dalam berbahasa. Tarigan (2011: 60) menyatakan bahwa kesalahan berbahasa itu disebabkan oleh perbedaan sistem bahasa pertama (B1) siswa dengan bahasa kedua (B2) yang dipelajarinya. Kesalahan berbahasa tidak hanya dibuat oleh pembelajar yang mempelajari
B2 tetapi juga dibuat oleh pembelajar yang mempelajari Bl-nya.

Hal tersebut menunjukkan bahwa kesalahan berbahasa itu erat kaitannya dengan pengajaran bahasa, baik pengajaran bahasa B1 maupun B2. Menurut Sutedi (2011: 1) baik pengajar maupun pembelajar bahasa Jepang perlu memahami atau minimal mengetahui tentang lingustik bahasa Jepang. Pengetahuan lingustik merupakan media untuk mempermudah dan memperlancar pemahaman dan penguasaan bahasa Jepang. Kesalahan berbahasa pada pembelajar, umumnya terjadi karena adanya transfer negatif bahasa ibu dengan bahasa Jepang. Kesalahan yang muncul bisa berupa penggunaan partikel, penggunaan kosakata, penggunaan pola kalimat dan sebagainya. Apabila melihat dari segi 
penggunaan pola kalimat yang digunakan, ada beberapa penggunaan pola kalimat yang memiliki makna yang sama dalam bahasa Indonesia, namun dalam bahasa Jepang berbeda. Diantaranya adalah dalam pola ungkapan ahasa Indonesia, biasanya ditandai dengan adanya pengandaian. Menurut Alwi (2000 : 269), jika, kalau, jikalau, asalkan, bila, manakala dan lain sebagainya merupakan konjungsi subordinat syarat atau dengan kata lain yaitu pengandaian bersyarat.

Sedangkan dalam bahasa Jepang Sutedi (2009: 147) menuturkan bahwa kalimat pengandaian disebut dengan jouken-bun. Kalimat pengandaian bahasa Jepang menggunakan kata kerja atau kata sifat bentuk $\sim$ ba, bentuk $\sim$ tara, bentuk kamus ditambah $\sim$ to, atau menggunakan kata $\sim$ nara. Sutedi dalam Nihongo no Bunpo (2009 : 151) memperlihatkan perbedaan keempat jenis pengandaian dengan contoh sebagai berikut:

1) 日本一行けば、私に連絡してください。 Nihon e ikeba, watashi ni renraku shite kudasai. Kalau akan pergi ke Jepang, tolong hubungi saya.

2) 日本へ行ったら、私に連絡してください。 Nihon e ittara, watashi ni renraku shite kudasai. Kalau (sudah) pergi ke Jepang, tolong hubungi saya.

3）日本へ行くなら、四月が一番いいです。 Nihon e iku nara, shigatsu ga ichiban ii desu. Kalau mau pergi ke Jepang, sebaiknya bulan april.

4）日本へ行くと、仕事は辞めてしまうんで す。

Nihon e iku to, shigoto wa yamete shimaun desu. Begitu pergi ke Jepang, maka akan berhenti bekerja.

Sutedi menjelaskan perbedaan contoh di atas antara lain sebagai berikut. Pada contoh (1) pembicara meminta pada orang (lawan bicara) yang akan pergi ke Jepang untuk menghubunginya, sebelum ia pergi ke Jepang. Sedangkan pada contoh (2) pembicara meminta dihubungi setelah orang tersebut pergi. Artinya yang bersangkutan akan menghubunginya setelah tiba di Jepang. Jadi di sini perbedaan $b a$, dan tara jelas sekali, yaitu setelah dan sebelum pergi. Pada contoh (3) digunakan nara, A berkata pada B bahwa dia akan pergi ke Jepang, ia meminta saran / pendapat B kapan sebaiknya pergi ke Jepang. Kemudian B memberikan saran bahwa bulan April paling baik, sebab bisa melihat bunga sakura dan sebagainya. Sehingga $\sim$ nara-lah yang digunakan. Pada contoh (4) to digunakan. Jika pernyataan pertama dan pernyataan kedua merupakan hubungan yang bersifat alami atau secara otomatis akan terjadi.

Berikut ini adalah teori yang mendasari penggunaan bentuk kalimat pengandaian bahasa Jepang, yaitu sebagai berikut.

\section{To「と」}

Penggunaan pola kalimat pengandaian $\sim$ to yaitu bentuk $\sim$ to mengikuti kata kerja bentuk kamus atau $\sim$ to berada sebelum kata kerja bentuk kamus. Penggunaan bentuk $\sim$ to dalam kalimat Menurut Iori dan Hasunuma dalam Nihongo no Bunpou Handobukku, yaitu pertama, klausa bawahan (kalimat awal) menjadi syarat terjadinya perkiraan klausa inti (kalimat akhir). Pada dasarnya berhubungan dengan makna perkiraan alamiah, cara pengoperasian mesin, penemuan, kebiasaan atau aktivitas yang berlangsung. Seperti contoh di bawah ini.

5) 三月の後半になると、桜が咲き始め ます。

Sangatsu no kouhan ni naruto, sakura ga sakihajimemasu.

Begitu masuk paruh kedua bulan tiga, sakura mulai mekar.

6）お金を入れて、ボタンを押すと、切 符が出てきます。

Okane wo irete, botan wo osuto, kippu ga detekimasu.

Begitu memasukan uan dan menekan tombol ini, tiketnya keluar.

7）四つ角を曲がると、すぐ彼のマンシ ヨンが見えた。

Yotsu kado wo magaruto, sugu kare no manshon ga mieta.

Begitu belok di perempatan, apartemen dia langsung terlihat.

8）毎朝起きると、紅茶をいっぱい飲み ます。

Maiasa okiru to, koucha wo ippai nomimasu.

Setiap pagi begitu bangun tidur, minum secangkir kopi. 
Penggunaan $\sim$ to yang kedua yaitu dengan klausa kedua atau kalimat dibelakangnya tidaj bisa menggunakan ungkapan maksud, harapan, perintah, dan permintaan. Kalimat belakang atau klausa kedua biasanya berupa kata kerja perubahan henka no kekka wo arawasu doushi $\sim$ narimasu, kata kerja keadaan joutai wo arawasu doushi imasu, arimasu, te imasu, kata kerja intransitive jidoushi $\sim$ demasu, $\sim$ sakimasu, $\sim$ furimasu, $\sim$ narabimasu, dan lain sebagainya.

9) 桜が咲くと、花見に行くつもりだ。

(X)

Sakura ga saku to, hanami ni iku tsumori da.

Kalau bunga sakuranya mekar, berencana pergi hanami

10) 食事ができると、呼んでください。 (X)

Shokuji ga dekiru to, yonde kudasai.

Kalau makanannya sudah jadi, tolong panggil.

Penggunaan pengandaian $\sim$ to yang ketiga yaitu baik klausa pertaa atau kedua bisa berupa kalimat lampau atau kejadian tersebut terjadi sebelumnya. Seperti contoh di bawah ini.

11)空を開けてると、冷たい風が入って きました。

Mado wo aketeru to, tsumetai kaze ga haitte kimashita.

Begitu membuka jendela, angina yang dingin masuk.

12) 田中さんにメールを送ると、すぐ返 事が来ました。

Tanaka san ni meeru wo okuru to, sugu henji ga kimashita.

Begitu mengirim pesan kepada Tanaka, balasannya langsung datang.

Penggunaan pengandaian $\sim$ to keemapat yaitu menunjukan pengandaian yang bersifat hipotesis, kalimat akhirnya bisa menunjukan hasil yang buruk. Hal yang dimaksud untuk ungkapan peringatan bagi lawan bicara. Seperti contoh berikut.

13) 真面目に勉強しないと、卒業できな いよ。

Majime ni bekyoushinai to, sotsugyou dekinai yo

Kalau menekan tombol ini, jadi bagaimana?

14) そんなにたくさん食べると、あとで お腹が痛くなる。
Sonna ni takusan taberu to, atode onaka ga itaku naru.

Kalau makan sebanyak itu, nanti perutnya menjadi sakit loh.

Penggunaan pengandaian $\sim$ to kelima yaitu bisa menyambungkan aktifitas berkelanjutan yang dilakukan subjek. Seperti contoh berikut.

15) コートを脱ぐと、ハンガーに掛けた。 Kooto wo nugu to, hangaa ni kaketa.

Begitu membuka mantel, menggantungkannya di gantungan.

\section{2. $\mathrm{Ba}$ 「ば」}

Suatu kata kerja bentuk kamus diubah ke dalam bentuk $\sim b a$, untuk golongan pertama vokal $U$ diubah menjadi $E$ ditambahkan $B A$, untuk golongan kedua ubah $R U$ menjadi $R E B A$, dan untuk golongan ketiga Suru berubah menjadi Sureba dan Kuru berubah menjadi Kureba.

Dalam buku Nihongo no Bunpo Handobukku Iori dkk (2000 : 222) menyatakan beberapa hal yang berkaitan dengan ungkapan pengandaian $\sim b a$ lebih cenderung menunjukan arti katei jouken (pengandaian) dari pada suatu kepastian. Seperti contoh berikut.

16)品がよく安ければ、よく売れます。 Hin ga yoku yasukereba, yoku uremasu.

Kalau barangnya bagus dan murah, laku sekali

Pengandaian $\sim b a$ tidak bisa diikuti oleh ungkapan maksud, harapan, perintah, dan permintaan. Seperti contoh berikut.

17) 駅に着けば、迎えに来てください。 Eki ni tsukeba, mukae ni kitekudasai Kalau tiba di stasiun tolong jemput.

Pengandaian $\sim b a$ jika klausa pertama berupa kata sifat $i$ dan na, kata benda dan $\mathrm{X}$ menggunakan ungkapan aru, dekiru dan lain-lain maka bisa diikuti oleh ungkapan maksud, harapan, perintah, dan permintaan. Seperti contoh berikut.

18) 分からないことがあれば、いつでも 聞いてください。

Wakaranai koto ga areba, itsudemo kite kudasai.

Kalau ada hal yang tidak dimengerti tolong bertanya kapan pun. 
Pengandaian $\sim b a$ tidak bisa menunjukan sesuatu yang lampau atau telah terjadi sebelumnya. Seperti contoh berikut.

19) 朝起きれば、雨が降っていた。(X) Asa okireba, ame ga futteita.

Kalau bangun pagi, sudah turun hujan.

Pengandaian $\sim b a$ pada kalimat akhir $(\mathrm{Y})$ tidak bisa menunjukan hasil yang tidak baik. Seperti contoh berikut.

20)この薬を飲めば、気分が悪くなりま す。

Kono kusuri wo nomeba, kibun ga waruku narimasu.

Kalau minum obat ini, menjadi merasa tidak sehat.

\section{Tara「たら」}

Bentuk tara terbentuk dari kata kerja bentuk $\sim t a$ atau kata sifat bentuk kata kemudian ditambah $\sim$ ra. Menurut Iori (2000 : 224) tara digunakan untuk pengandaian dan juga bisa digunakan untuk pengandaian ketetapan atau ketentuan tersendiri. Lalu dapat juga digunakan untuk pengandaian yang pada klausa kedua diikuti bentuk kemauan, perintah, permintaan serta bentuk kewajiban.

21) 雨が降ったら、キャンプは中止です。 Ame ga futtara, kyanpu wa chuushi desu.

Kalau hujan turun, perkemahan dihentikan.

22) 午後になったら、散歩に行きましょ う。

Gogo ni nattara, sanpo ni ikimashou

Kalau sudah sore, ayo pergi jalan-jalan.

23）山本さんに会ったら、よろしく伝え

てください。

Yamamoto san ni attara, yoroshiku tsutaete kudasai

Kalau bertemu tuan yamamoto, tolong sampaikan salam.

Hasunuma (2010:8) Pengandaian $\sim$ tara X merupakan hipotesis, sedangkan Y menunjukan hasil yang sepertinya terjadi. Jika di awal kalimat dibubuhi kata moshi maka hipotesisnya menjadi tinggi. Seperti contoh berikut.
24）もし気が付くのが一秒でも遅かった ら、大惨事になっていただろう。

Moshi ki ga tsuku no ga ichibyou demo osokattara, daisanji ni natteitadarou.

Kalau terlambat menyadari walau hanya satu detik pun, akan terjadi kecelakaan besar kan?

Kemudian pengandaian $\sim$ tara $\mathrm{X}$ juga bisa bertanya tentang kondisi $X$, juga bisa bertanya tentang hasil Y. Seperti contoh berikut.

25) どうしたら、やせることができるで しょうか。

Doushitara, yaserukotoga dekiru deshouka. Bagaimana agar bisa kurus?

Selanjutnya pengandaian $\sim$ tara $\mathrm{X}$ bisa menunjukan hasil yang baik dan buruk. Seperti contoh berikut.

26)この薬を飲んだら、もつとお腹が痛 くなりますよ。

Kono kusuri wo nondara, motto onaka ga itaku narimasuyo.

Kalau minum obat ini, perut akan menjadi semakin sakit loh.

Menurut Yokobayashi dan Shimomua (2008) menyatakan pemakaian bentuk pengandaian tara menunjukan urutan waktu dimana setelah apa yang diungkapkan pada klausa pertama terjadi, maka dilakukan apa yang diungkapkan pada klausa akhir. Biasanya pada klausa akhir terdapat harapan, maksud, kemauan, dan lain sebagainya. Seperti contoh berikut.

27) 明日の朝早く起きられたら、ジョギ ングをしよう。

Ashita no asa hayaku okiraretara, jogingu wo shiyou.

Kalau besok pagi bangun cepat, ayo kita jogging.

\section{Nara「なら」}

Bentuk pengandaian nara dalam kalimat pengandaian digunaan mengikuti kata kerja atau kata sifat $I$ dalam bentuk kamus, dan jika kata sifat na berubah menjadi nara atau naraba. Menurut Hasunuma (2008) penggunaan nara pada saat merespon lawan bicara atau maksud 
dan rencana yang dikatan lawan bicara dalam percakapan.

28)「明日のコンサートに行くことにし たよ」

Ashita no konsaato ni iku koto ni shita yo. Saya telah memutuskan untuk pergi ke konser besok loh.

「あなたが行くなら、私も行くわ」

Anata ga iku nara, watashi mo iku wa

Kalau kamu pergi, saya juga pergi.

Kemudian pengandaian $~ n a r a$ berfungsi untuk mengangkat topik mengenai hal yang bisa diperkiraan dari sisi percakapan sebelumnya dan dari isi yang dikatakan oleh lawan bicara, sedangkan $\mathrm{Y}$ menunjukan respon berupa maksud dan keputusan bagi lawan bicara. Seperti contoh berikut.

29）「大学を卒業したら、留学したいと 思っているんだ。」

Daigaku wo shitara, ryungaku shitai to omotteirun da.

Setelah lulus dari universitas, bermaksud ingin studi ke luar negeri

「留学するのならオーストラリアが 良いよ。」

Ryungaku suru no nara oosutoraria ga ii yo. Kalau studi luar negeri, Australia bagus loh.

Pengandaian nara dapat menambahkan bentuk ta + nara yang menunjukan bahwa $\mathrm{X}$ adalah hipotesis mengenai masa yang akan datang, sedangkan Y menunjukan permintaan atau mmaksud diri sendiri dan keputusan berdasarkan pada hipotesis. Seperti contoh berikut.

30) 60 点以上取ったなら、数学科に進む ことにするよ。

Roku juu ten ijou totta nara, suugakuka ni susumu koto ni suru yo.

Kalau bisa mendapat nilai di atas 60 , bisa melanjutkan ke jurusan matematika loh.

Kemudian nara juga menunjukan klausa pertama merupakan hipotesis di masa lampau dan klausa kedua merupakan hipotesis berlawanan dengan fakta di masa lampau. Seperti contoh berikut.

31）もつと注意をしていたなら、事故は 起こらなかっただろう。
Motto chuui wo shiteita nara, jiko wa okoranakatta darou.

Kalau tadinya lebih fokus lagi, kecelakaannya tidak akan terjadi kan.

Teori yang telah dipaparkan di atas, merupakan acuan bagi penulis dalam melakukan analisis kesalahan mahasiswa dalam menggunakan jouken hyougen. Untuk melihat ada kesalahan dalam menggunakan jouken hyougen tersebut, penulis melakukan penelitian pada pembelajar bahasa Jepang level menengah ke atas dari berbagai Universitas maupun lembaga yang menyelenggarakan pelatihan bahasa Jepang. Atas dasar pemikiran tersebut, penulis bermaksud untuk melakukan penelitian lebih lanjut dengan judul "Kesalahan Penggunaan Jouken Hyougen Pada Pembelajar Bahasa Jepang Level Menengah Atas".

Berdasarkan latar belakang masalah yang telah penulis utarakan di atas, maka rumusan masalah dalam penelitian yaitu :

1. Kesalahan apa yang sering muncul pada pembelajar bahasa Jepang level menengah atas dalam menggunakan jouken hyougen?

2. Bagaimanakah upaya yang harus dilakukan untuk meminimalisir kesalahan?

\section{METODE}

Dalam melaksanakan penelitian ini, pendekatan yang digunakan adalah pendekatan deskriptif, yaitu penelitian yang dilakukan semata-mata hanya berdasarkan pada faktafakta yang ada atau fenomena yang secara empiris hidup pada penuturnya sehingga yang dihasilkan atau yang dicatat berupa perihal bahasa yang biasa dikatakan sifatnya seperti potret atau paparan seperti apa adanya (Sudaryanto, 1992 : 62 dalam Muhammdad, 2011 : 192).

Penelitian ini menggunakan instrument berupa tes, karena dianggap paling sesuai untuk mencari letak kesalahan-kesalahan yang sering muncul dalam penggunaan jouken hyougen. Sebanyak 10 soal yang berisi mengenai jouken hyougen to, tara, nara dan ba. Dari 10 soal tersebut terdapat 2 tipe soal, yaitu 5 soal berbentuk 
menerjemahkan ke dalam bahasa Jepang serta diberikan kata kunci untuk menerjemahkan soal yang diberikan dan 5 soal berbentuk true or false (benar atau salah). Setelah dilakukan tes terhadap responden, kemudian melakukan wawancara melalui media sosial dengan subjek penelitian. Hal ini dilakukan untuk mengetahui penyebab kesalahan penggunaan jouken hyougen.

Subjek penelitian ini adalah pembelajar bahasa Jepang level menengah atas atau pembelajar dengan kemampuan berbahasa Jepang level 3 ke atas (JLPT N3 hingga JLPT N1) di beberapa Universitas di Indonesia seperti Universitas Negeri Semarang, Universitas Pendidikan Indonesia, Universitas Brawijaya, Universitas Muhamadiyah Yogyakarta, Sekolah Tinggi Bahasa Asing Bandung, Universitas Negeri Jakarta, dan Universitas Diponegoro. Kemudian beberapa pembelajar yang memiliki kemampuan bahasa Jepang level JLPT N3 atau lebih di lembaga pendidikan seperti Lembaga Pelatihan Kerja (LPK) dan Nihongo gakkou 'sekolah bahasa Jepang' di Jepang pun dijadikan subjek penelitian.

Menurut Tarigan (2011: 62) harus diakui metode analisis kesalahan bersifat ortodoks dalam arti tidak berkembang dari dahulu sampai sekarang. Sehingga Tarigan mengajukan modifikasi langkah-langkah analisis kesalahan sebagai berikut. I) Mengumpulkan data: berupa kesalahan berbahasa yang dilakukan oleh siswa. 2) Mengidentifikasi dan mengklasifikasi kesalahan: mengenali dan memilah- milah kesalahan berdasarkan kategori kebahasaan, misalnya kesalahan- kesalahan pelafalan, pembentukan kata, penggabungan kata, penyususnan kaliamat. 3) Memperingkat kesalahan: mengurutkan letak kesalahan, penyebab kesalahan dan memberikan contoh yang benar. 4) Menjelaskan kesalahan: menggambarkan letak kesalahan, penyebab kesalahan dan memberikan contoh yang benar. 5) Memperkirakan atau memprediksi daerah atau hal kebahasaan yang rawan: Meramalkan tataran bahasa yang dipelajari yang potensial mendatangkan kesalahan. 6) Mengoreksi kesalahan: memperbaiki dan bila dapat menghilangkan kesalahan melalui penyusuna bahan yang tepat, buku pegangan yang baik dan teknik pengajaran yang serasi.

\section{HASIL DAN PEMBAHASAN}

1. To「と」

1) Frekuensi dan Presentase Kesalahan pada Penggunaan To

\begin{tabular}{lccl}
\hline \multicolumn{1}{c}{ Kategori } & No Soal & $\mathbf{F}$ & $\mathbf{P ~ ( \% )}$ \\
\hline$\sim$ と & 2 & $7 / 37$ & $18,9 \%$ \\
$\sim T_{0}$ & & $10 / 37$ & $27 \%$ \\
& 3 & & \\
\cline { 2 - 4 } & 4 & $6 / 37$ & $16.2 \%$ \\
\cline { 2 - 4 } & 6 & $19 / 37$ & $51.3 \%$ \\
\hline & 7 & $20 / 37$ & $54 \%$ \\
\hline
\end{tabular}

Pada kategori To terdapat 5 soal yang di dalamnya juga terdapat soal yang memiliki jawaban jouken hyougen yang lain selain to. Berdasarkan tabel di atas dapat diketahui bahwa sebanyak 2 soal yang yang kesalahannya mencapai lebih dari $50 \%$ yaitu pada soal nomor 6 dan 7. Hal ini membuktikan bahwa responden atau pembelajar bahasa Jepang level menengah atas (JLPT N3 hingga N1) masih sering terjadi kesalahan pada pengandaian bentuk $\sim$ to.

\section{2) Pemaparan Data dan Pembahasan}

Tentang Kesalahan Penggunaan To

\begin{tabular}{cll}
\hline $\begin{array}{c}\text { No } \\
\text { Soal }\end{array}$ & $\begin{array}{c}\text { Soal dan Jawaban } \\
\text { Benar }\end{array}$ & $\begin{array}{c}\text { Presentase } \\
\text { Jawaban } \\
\text { Salah }\end{array}$ \\
\hline \multirow{3}{*}{ Soal : } & 人 \\
& Begitu lulus \\
& universitas maka & \\
& akan bekerja di \\
& perusahaan \\
& Jepang. \\
& 「日本」「大 \\
& 「学」「働く」 \\
& 「卒業する」 \\
& 「会社」
\end{tabular}

Jawaban : 
大学を卒業する

と、日本の会社

で働きます。

大学を卒業した

ら、日本の会社

で働きます。

\begin{tabular}{llll}
\hline \multicolumn{4}{c}{ Pilihan Jawaban Responden } \\
\hline$\sim$ To & $\sim$ Tara & $\sim$ Nara & $\sim$ Ba \\
\hline 10 人 & 21 人 & 1 人 & 6 人 \\
$(27 \%)$ & $(56.7 \%)$ & $(2,7 \%)$ & $(16,2 \%)$ \\
\hline
\end{tabular}

Pada soal nomor 2 di atas, presentase kesalahan sebanyak $18,9 \%$ atau 7 orang yang menjawab salah. Pada soal ini menunjukan pembelajar sudah cukup memahami penggunaan $\sim$ tara dan $\sim$ to yang menunjukan makna kepastian. Namun ada 6 responden yang menjawab $\sim b a$ mengaku lupa kalau pengandaian $\sim b a$ tidak bisa menyatakan pengandaian yang pasti.

\begin{tabular}{cll}
\hline $\begin{array}{c}\text { No } \\
\text { Soal }\end{array}$ & $\begin{array}{c}\text { Soal dan Jawaban } \\
\text { Benar }\end{array}$ & $\begin{array}{c}\text { Presentase } \\
\text { Jawaban } \\
\text { Salah }\end{array}$ \\
\hline & Soal : & $\begin{array}{l}10 \text { 人 } \\
(27 \%)\end{array}$ \\
& $\begin{array}{l}\text { Kalau tidak belajar } \\
\text { dengan sungguh- }\end{array}$ & \\
& sungguh, tidak \\
& bisa lulus loh. \\
& 「勉強しない」 & \\
& 「できない」「ま \\
& じめ」「卒業」 \\
&
\end{tabular}

Jawaban :

まじめに勉強しな

いと、卒業できな

いよ。
まじめに勉強しな かったら、卒業で

きないよ。

Pada soal nomor 3 memiliki presentase kesalahan sebanyak $27 \%$ atau 10 orang responden menjawab salah. Pada kalimat ini merupakan pengandaian atau ketetapan tersendiri pada penggunanya. Pengandaian $\sim b a$ tidak dapat digunakan dalam konteks kalimat tersebut, karena $\sim b a$ tidak bisa menunjukan hasil yang buruk pada klausa keduanya. Berdasarkan wawancara dengan responden, responden yang menjawab salah mengaku tidak mengetahui aturan penggunaan $\sim b a$ dan $\sim$ nara yang tidak bisa diakhiri dengan nuansa negative. Dapat disimpulkan bahwa responden memahami mengenai penggunaan pengandaian dalam kontesk tersebut.

\begin{tabular}{|c|c|c|c|c|}
\hline \multirow{2}{*}{$\begin{array}{c}\text { No } \\
\text { Soa } \\
1\end{array}$} & Soal dan & $\begin{array}{l}\text { Prese } \\
\text { ntase }\end{array}$ & \multicolumn{2}{|c|}{$\begin{array}{l}\text { Pilihan } \\
\text { Jawaban }\end{array}$} \\
\hline & $\begin{array}{c}\text { Jawaban } \\
\text { Benar }\end{array}$ & $\begin{array}{c}\text { Jawa } \\
\text { ban } \\
\text { Salah }\end{array}$ & $\mathbf{O}$ & $\mathbf{X}$ \\
\hline & $\begin{array}{l}\text { Soal： } \\
\text { 制服を脱ぐ } \\
\text { と、ハンガ } \\
\text { 一に掛け } \\
\text { た。 }\end{array}$ & $\begin{array}{l}19 \text { 人 } \\
(51,3 \\
\%)\end{array}$ & 18 人 & 19 人 \\
\hline
\end{tabular}

6

Jawaban :

制服を脱ぐ

と、ハンガ

一に掛け

た。 
Pada soal nomor 6 di atas, presentase kesalahan sebanyak $51,3 \%$ atau 19 orang yang menjawab salah. Pada soal ini menunjukan penggunaan $\sim$ to untuk hal yang bersifat umum dan pada konteks ini merupakan kalimat yang menunjukan rentetan aktifitas atau pergerakan. Pembelajar bahasa Jepang yang menjawab salah, ketika diwawancarai mengaku baru mengetahui aturan penggunaan pengandaian bentuk $\sim$ to dalam konteks tersebut. Sebagian responden mengaku kebingungan dalam menentukan pengandaian yang tepat untuk konteks tersebut.

\begin{tabular}{lllll}
\hline No & Soal dan & Presentas & \multicolumn{2}{c}{ Pilihan } \\
Soal & $\begin{array}{c}\text { Jawaban } \\
\text { Benar }\end{array}$ & $\begin{array}{c}\text { Jawaban } \\
\text { Salah }\end{array}$ & O & X \\
& Soal : & 20 人 & 20 & 17 \\
& この薬を飲 & $(54 \%)$ & 人 & 人 \\
& めば、頭痛 & & & \\
が治ってい & & & \\
た。 & & &
\end{tabular}

Jawaban :

7 この薬を飲

んだら、頭

痛が治って

いた。

この薬を飲

むと、頭痛

が治ってい

た。

Pada soal nomor 7 di atas, presentase kesalahan sebanyak $54 \%$ atau 20 orang yang menjawab salah. Pada soal ini responden tidak mengetahui bahwa ketika klaussa kedua merupakan kalimat lampau, pengandaian $\sim b a$ tidak dapat digunakan. Pembelajar bahasa Jepang yang menjawab salah, ketika diwawancarai mengaku baru mengetahui aturan penggunaan pengandaian

Gilang Auliya Prasetyo Widodo, Dedi Sutedi. (2020).

J-Litera: Jurnal Kajian Bahasa, Sastra, dan Budaya Jepang. Vol.2 (2) pp. 56-68. bentuk $\sim$ to dalam konteks tersebut. Sebagian responden mengaku kebingungan dalam menentukan pengandaian yang tepat untuk konteks tersebut.

2. Tara「たら」

1) Frekuensi dan Presentase Kesalahan pada Penggunaan Tara

\begin{tabular}{|c|c|c|c|}
\hline Kategori & No Soal & $\mathbf{F}$ & P (\%) \\
\hline 〜たら & 1 & $13 / 37$ & $35.1 \%$ \\
\hline \multirow{5}{*}{$\sim$ Tara } & 2 & $7 / 37$ & $18,9 \%$ \\
\hline & 3 & $10 / 37$ & $27 \%$ \\
\hline & 7 & $20 / 37$ & $54 \%$ \\
\hline & 9 & $32 / 37$ & $86,4 \%$ \\
\hline & 10 & $15 / 37$ & $40,5 \%$ \\
\hline
\end{tabular}

Pada kategori Tara terdapat 6 soal yang di dalamnya juga terdapat soal yang memiliki jawaban jouken hyougen yang lain selain tara. Berdasarkan tabel di atas dapat diketahui bahwa sebanyak 2 soal yang kesalahannya mencapai lebih dari 50\% yaitu pada soal nomor 7 dan soal nomor 9. Hal ini membuktikan bahwa responden atau pembelajar bahasa Jepang level menengah atas (JLPT N3 hingga N1) masih sering terjadi kesalahan pada pengandaian bentuk $\sim$ tara.

2) Pemaparan Data dan Pembahasan Tentang Kesalahan Penggunaan Tara

\begin{tabular}{|c|c|c|}
\hline $\begin{array}{l}\text { No } \\
\text { Soal }\end{array}$ & $\begin{array}{c}\text { Soal dan Jawaban } \\
\text { Benar }\end{array}$ & $\begin{array}{c}\text { Presentase } \\
\text { Jawaban } \\
\text { Salah }\end{array}$ \\
\hline \multirow{3}{*}{1} & $\begin{array}{l}\text { Soal: } \\
\text { Kalau ada uang } \\
10.000 .000 \\
\text { rupiah, membeli } \\
\text { apa? }\end{array}$ & \multirow[t]{3}{*}{$\begin{array}{l}13 \text { 人 } \\
(35,1 \%)\end{array}$} \\
\hline & $\begin{array}{l}\text { 「チ万ルピア」 } \\
\text { 「買う」「あ } \\
\text { る」「何」 }\end{array}$ & \\
\hline & Jawaban: & \\
\hline
\end{tabular}


千万ルピアがあ

ったら、何を買

いますか。

\begin{tabular}{llll}
\hline \multicolumn{4}{c}{ Pilihan Jawaban } \\
\hline$\sim$ To & $\sim$ Tara & $\sim$ Nara & $\sim \boldsymbol{B a}$ \\
\hline 5 人 & 24 人 & 0 人 & 8 人 \\
$(13,5 \%)$ & $(64,8 \%)$ & $(0 \%)$ & $(21,6 \%)$ \\
\end{tabular}

Pada soal nomor 1 memiliki presentase kesalahan sebanyak $35,1 \%$ atau 13 orang responden menjawab salah. Berdasarkan tabel di atas dapat dikatakan bahwa pembelajar bahasa Jepang tingkat menegah atas sudah tergolong memahami penggunaan kalimat pengandaian $\sim$ tara. Pada kalimat ini jika klausa keduanya terdapat kata tanya, maka jenis pengandaian yang paling tepat untuk konteks tersebut adalah $\sim$ tara. Responden yang menjawab $\sim b a$ mengaku tidak asing dengan ungkapan pengandaian $\sim b a$ dalam $\sim$ areba tanpa mengetahui aturan yang berlaku, sehingga memilih menjawab pengandaian bentuk $\sim b a$.

\begin{tabular}{|c|c|c|c|c|}
\hline $\begin{array}{l}\text { No } \\
\text { Soal }\end{array}$ & $\begin{array}{c}\text { Soal dan } \\
\text { Jawaban } \\
\text { Benar }\end{array}$ & $\begin{array}{c}\text { Presentase } \\
\text { Jawaban } \\
\text { Salah }\end{array}$ & $\begin{array}{c}\text { Pili } \\
\text { Jawa } \\
\text { O }\end{array}$ & $\begin{array}{c}\text { an } \\
\text { ban } \\
X\end{array}$ \\
\hline & $\begin{array}{l}\text { Soal : } \\
\text { もし } 4 \text { 時 } \\
\text { になった } \\
\text { ら、さき } \\
\text { に帰って } \\
\text { もいい } \\
\text { よ。 }\end{array}$ & $\begin{array}{l}32 \text { 人 } \\
(86,4 \%)\end{array}$ & $\begin{array}{l}32 \\
\text { 人 }\end{array}$ & $\begin{array}{l}5 \\
\text { 人 }\end{array}$ \\
\hline
\end{tabular}

9

Jawaban :

$$
\begin{aligned}
& 4 \text { 時にな } \\
& \text { ったら、 } \\
& \text { さきに帰 } \\
& \text { ってもい } \\
& \text { いよ。 }
\end{aligned}
$$

Pada soal nomor 9 memiliki presentase kesalahan sebanyak $86,4 \%$ atau 32 orang responden menjawab salah. Pada soal ini menunjukan pengandaian yang berhubungan dengan waktu dan kententuan pengandaian yang berhubungan dengan waktu tidak bisa atau salah jika terdapat kata moshi.

Mayoritas responden menjawab kalimat ini benar karena memang penggunaan kata moshi bisa diikuti bentuk pengandaian $\sim$ tara Berdasarkan hasil wawancara dengan responden, para responden mengaku baru mengetahui ada aturan tersebut. Responden hanya mengetahui bahwa moshi sudah satu set dengan $\sim$ tara.

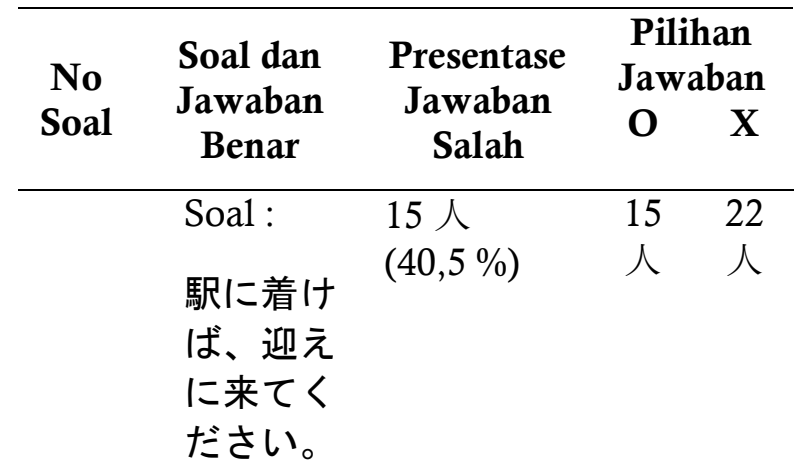

10

Jawaban :

駅に着い

たら、迎

えに来て

くださ

い。

Pada soal nomor 10 memiliki presentase kesalahan sebanyak $40,5 \%$ atau 15 orang responden menjawab salah. Pada soal ini, klausa kedua adalah bentuk perintah dengan pemarkah leksikal te kudasai yang artinya 'menyuruh', sehingga pengandaian yang tepat adalah tara. Responden yang menjawab benar, mengaku lupa kalau pengandaian $\sim b a$ dan pengandaian $\sim$ to tidak bisa diakhiri dengan bentuk perintah. Namun jika dilihat dari presentase kesalahan, responden dapat dikatan cukup memahami penggunaan pengandaian tara dalam konteks tersebut. 


\section{Nara「なら」}

1) Frekuensi dan Presentase Kesalahan pada Penggunaan Nara

\begin{tabular}{lccc} 
Kategori & No Soal & $\mathbf{F}$ & $\mathbf{P ~ ( \% )}$ \\
\hline$\sim$ なら & 5 & $22 / 37$ & $59,4 \%$ \\
\cline { 2 - 4 }$\sim$ Nara & 8 & $22 / 37$ & $59,4 \%$
\end{tabular}

Pada kategori Nara terdapat 2 soal yang menyatakan hanya bentuk pengandaian atau jouken hyougen nara adalah yang paling tepat. Berdasarkan tabel di atas dapat diketahui bahwa 2 dari 10 soal yang jawabannya nara memiliki kesalahan mencapai lebih dari 50\%. Hal ini membuktikan bahwa responden atau pembelajar bahasa Jepang level menengah atas (JLPT N3 hingga N1) masih sering terjadi kesalahan pada pengandaian bentuk $\sim$ nara.

\section{2) Pemaparan Data dan Pembahasan} Tentang Kesalahan Penggunaan Nara

\begin{tabular}{lll}
\hline $\begin{array}{c}\text { No } \\
\text { Soal }\end{array}$ & $\begin{array}{c}\text { Soal dan Jawaban } \\
\text { Benar }\end{array}$ & $\begin{array}{c}\text { Presentase } \\
\text { Jawaban Salah }\end{array}$ \\
\hline & Soal : & 22 人 \\
& Kalau mau pergi & $(59,4 \%)$ \\
& sekarang, bawa \\
pergi lah & \\
payung. & \\
& 「出かける」 \\
& 「持って行きな \\
& さい」「今」 \\
& 「傘」 \\
& \\
& \\
& Jawaban: \\
& 今、出かけるな \\
& ら、金を持って \\
& 行きなさい。 \\
&
\end{tabular}

Pada soal nomor 5 dapat diketahui bahwa persentase kesalahan sebanyak $59,4 \%$ atau 22 orang responden menjawab salah. Pada soal ini, jawaban yang paling tepat adalah nara karena pengandaian atau dugaan untuk kejadian yang terjadi pada waktu bersamaan.

Pembelajaran mengenai fungsi pengandaian nara secara detail tidak ada dalam buku pelajaran perkuliahan maupun buku pegangan pembelajaran yang dipakai di Indonesia. Dari 37 orang total responden, terdapat 15 responden menjawab benar. Menurut pengakuan responden yang menjawab dengan benar, mereka pernah membaca buku sumber yang membahas seputar kalimat pengandaian baik to, tara, $b a$, dan nara. Responden yang menjawab salah mengaku baru mengetahui ada aturan tersebut pada bentuk pengandaian nara.

\begin{tabular}{ccccc}
\hline No & Soal dan & Presentase & \multicolumn{2}{c}{ Pilihan } \\
Soal & $\begin{array}{c}\text { Jawaban } \\
\text { Bawar }\end{array}$ & $\begin{array}{c}\text { Jawaban } \\
\text { Salah }\end{array}$ & O & X \\
& Soal : & 15 人 & 15 & 22 \\
& もっと注 & $(59,4 \%)$ & 人 & 人 \\
& 意をして & & & \\
いたな & & & \\
& ら、事故 & & \\
は起こら & & & \\
なかった & & & \\
だろう。 & &
\end{tabular}

8

Jawaban :

もっと注

意をして

いたな

ら、事故

は起こら

なかった

だろう。

Pada soal nomor 8 dapat diketahui bahwa persentase kesalahan sebanyak $59,4 \%$ atau 22 orang responden menjawab salah. Pada soal ini, menunjukan pengandaian yang berlawanan dengan kenyataan yang terjadi. Kata kunci pada soal ini adalah motto chuui wo shiteita nara 'kalau lebih hati-hati lagi'. 
Pada klausa tersebut dapat dipahami bahwa kenyataannya pelaku tidak berhati-hati, maka dari itu terjadi kecelakaan. Pada konteks kalimat yang seperti ini, pengandaian nara adalah jawaban yang paling tepat.

Melalui wawancara kepada responden, mereka mengakui bahwa materi ini baru pertama diketahui. Maka dari itu banyak responden yang salah dalam menjawab soal dengan konteks tersebut.

\section{4. $B a$ 「ば」}

1) Frekuensi dan Presentase Kesalahan pada Penggunaan $\mathrm{Ba}$

\begin{tabular}{cccc}
\hline Kategori & No Soal & F & P (\%) \\
\hline$\sim$ & 4 & $6 / 37$ & $16,2 \%$ \\
$\sim B a$ & & & \\
\hline
\end{tabular}

Pada kategori $B a$ terdapat 1 soal yang di dalamnya juga terdapat soal yang memiliki jawaban jouken hyougen yang lain selain $b a$. Berdasarkan tabel di atas dapat diketahui bahwa responden cukup mengetahui baik mengenai penggunaan pengandaian bentuk $b a$ dalam hal yang bersifat alamiah.

\section{2) Pemaparan Data dan Pembahasan}

Tentang Kesalahan Penggunaan $\mathbf{B a}$

\begin{tabular}{cll}
\hline $\begin{array}{c}\text { No } \\
\text { Soal }\end{array}$ & $\begin{array}{c}\text { Soal dan Jawaban } \\
\text { Benar }\end{array}$ & $\begin{array}{c}\text { Presentase } \\
\text { Jawaban Salah }\end{array}$ \\
\hline & Soal : & 6 人 \\
& Begitu masuk & \\
& musim semi, \\
& sakura mulai \\
& mekar. \\
& 「さくら」「な \\
& る」「咲き始め \\
& る」「春」 \\
& Jawaban : \\
& 春になると、桜 \\
& が咲き始める。 \\
& 春になれば、桜 \\
& が咲き始める。 \\
&
\end{tabular}

\begin{tabular}{llll}
\hline \multicolumn{4}{c}{ Pilihan Jawaban } \\
\hline$\sim$ To & $\sim$ Tara & $\sim$ Nara & $\sim \boldsymbol{B a}$ \\
\hline \multirow{2}{*}{30 人 } & 6人 & 0 人 & 1 人 \\
& $(16,2 \%)$ & $(0 \%)$ & $(2,7 \%)$ \\
$(81 \%)$ & & & \\
\hline
\end{tabular}

Pada soal nomor 4 di atas, presentase kesalahan sebanyak $16,2 \%$ atau 6 orang yang menjawab salah. Pada soal ini menunjukan pembelajar sudah cukup memahami penggunaan $\sim$ to dan $\sim b a$ yang menunjukan pengandaian yang umum untuk perkiraan yang bersifat alamiah. Namun ada 6 responden yang menjawab tara mengaku bahwa tara menurut responden dapat dipakai dalam konteks apapun.

\section{Upaya Mengurangi Kesalahan}

Dalam mempelajari bahasa asing tidak semudah mempelajari bahasa ibu, karena dalam kehidupan sehari-hari bahasa asing tidak digunakan untuk menyampaikan suatu informasi kepada lawan bicara. Sehingga dalam menggunakan bahasa asing masih terbilang kaku dan sering mengalami kesalahan. Termasuk kesalahan dalam hal pengandaian yang telah dibahas di atas.

Kesalahan penggunaan jouken hyougen pada penelitian ini, umumnya lebih disebabkan oleh ketidak tahuan responden akan aturan penggunaan jouken hyougen $\sim$ to, $\sim$ tara, $\sim$ nara, dan $\sim b a$. Kesalahan juga terjadi karena tingkat pemahaman responden terhadap materi jouken hyougen yang masih rendah, meskipun responden dapat dikatakan memiliki kemampuan berbahasa Jepang level menengah atas.

Kesalahan terbanyak terdapat pada materi pengandaian tara yang berhubungan dengan waktu dan kententuan pengandaian yang berhubungan dengan waktu tidak bisa atau salah jika terdapat kata moshi.

Peran pengajar untuk meminimalisir kesalahan yaitu mengoptimalkan pengajar untuk mengevaluasi pemahaman dari para pembelajar, karena pembelajar mengenal istilah kalimat pengandaian dari seorang 
pengajar. Jika pengajar tidak optimal dalam mengevaluasi pemahaman pembelajar, maka tidak menutup kemungkinan pembelajar akan mengalami kesalahan dalam menggunakan pengandaian to, tara, nara, $b a$. Berikutnya, pengajar juga memberikan arahan dan motivasi kepada pembelajar untuk mencari tahu sendiri materi yang berhubungan dengan kalimat pengandaian di berbagai sumber, supaya pengetahuan pembelajar semakin meningkat. Dan juga bertanya pada penutur asli bahasa Jepang (native speaker) jika ingin mengetahui konteks penggunaan pengandaian to, tara, nara, $b a$.

\section{SIMPULAN}

Kesalahan berbahasa pada pembelajar, umumnya terjadi karena adanya transfer negatif bahasa ibu dengan bahasa Jepang. Kesalahan yang muncul bisa berupa hal apapun, misalnya penggunaan partikel, penggunaan kosakata, penggunaan pola kalimat dan sebagainya.

Upaya untuk meminimalisir kesalahan yaitu mengoptimalkan kinerja pengajar untuk mengevaluasi pemahaman dari para pembelajar. Berikutnya, pengajar juga memberikan arahan dan motivasi kepada pembelajar untuk mencari tahu sendiri materi yang berhubungan dengan kalimat pengandaian di berbagai sumber, supaya pengetahuan pembelajar semakin meningkat. Dan juga bertanya pada penutur asli bahasa Jepang (native speaker) jika ingin mengetahui konteks penggunaan pengandaian to, tara, nara, ba.

\section{REFERENSI}

Hasunuma, A. 2010. Jouken Hyougen. Tokyo : Kuroshio Shuppan.

Iori, I. 2000. Shokyuu o Oshieru Hito no Tame no Nihongo Bunpou Handobukku. Tokyo.

Mayantara School. 2019. Tersedia di : https://mayantara.sch.id/artikel/surveilembaga-pendidikan-bahasa-jepang-diindonesia-tahun-2012.html
Muhammad. 2011. Metode Penelitian Bahasa. Yogyakarta: Ar-Ruzz Media.

Subakti, Ernawati. "Hubungan Penguasaan Konjungsi dengan Kemampuan Menulis Kalimat Berita Siswa BT-BS Bima Cabang Lhokseumawe Tahun 2010" dalam Jurnal Mutiara Ilmu Vol. 6 No. 1. Maret 2011

Sutedi, Dedi. 2002. Nihongo No Bunpou. Bandung : Humaniora

2009. Penelitian Pendidikan Bahasa Jepang (Panduan bagi guru dan calon guru dalam meneliti Bahasa Jepang dan pengajarannya)). Bandung : Humaniora

2011. Dasar-dasar Linguistik Bahasa Jepang. Bandung : Humaniora

Tarigan. 2011. Pengajaran Analisis Kesalahan Berbahasa. Bandung : Angkasa 